\title{
Response of vegetation to fire disturbance: short-term dynamics in two savanna physiognomies
}

\author{
D. B. das Chagas ${ }^{1}$ and F. M. Pelicice 2
}

1Programa de Pós-Graduação em Ecologia de Ecótonos (current Biodiversidade, Ecologia e Conservação), Universidade Federal do Tocantins, Rua 03 Qd 17 S/N, Porto Nacional - Tocantins, Brasil, 77500-000. Current affiliation: Programa de Pós-Graduação em Botânica - PPGBot, Universidade Estadual de Feira de Santana, Av. Universitária, s/n Feira de Santana - Bahia, 44.036-900, Brasil. Corresponding author. E-mail: davibchagas@gmail.com

${ }^{2}$ Núcleo de Estudos Ambientais, Universidade Federal do Tocantins, Porto Nacional, Tocantins, Rua 03 Qd 17 S/N, 77500-000, Brasil

Keywords: Cerrado, Community assembly, Composition, Resilience, Species richness, Temporal trajectory.

\begin{abstract}
Fire is a constitutive ecological force in savanna ecosystems, but few studies have monitored its short-term effects on plant community dynamics. This study investigated changes in plant diversity in the South American savanna (Cerrado) after severe disturbance by fire. We monitored 30 permanent plots $(10 \mathrm{~m} \times 5 \mathrm{~m})$ distributed in two Cerrado physiognomies (típico: more forested; ralo: grass-dominated), being 10 plots in the area disturbed by fire, and five in a preserved control area (undisturbed). From August 2010 to June 2011, we evaluated changes in species richness, abundance and composition of savanna vegetation. Monitoring started one week after the fire; disturbed plots were surveyed monthly, while control plots were surveyed every two months. We observed rapid reassembling in both physiognomies: plots affected by fire showed rapid increase in species richness and plant density during the first four months after the disturbance. Concerning species composition, disturbed plots in the cerrado típico tended to converge to control plots after one year, but each local assemblage followed particular temporal trajectories. A different pattern characterized cerrado ralo plots, which showed heterogeneous trajectories and lack of convergence between disturbed and control plots; the structure of these assemblages will likely change in next years. In conclusion, our results showed that fire significantly affected plant diversity in the two savanna physiognomies (cerrado típico and ralo), but also indicated that community reassembling is fast, with different dynamics between Cerrado physiognomies.
\end{abstract}

Abbreviations: APG - Angiosperm Phylogeny Group, cerrado ralo - RF, cerrado ralo control - RC, cerrado típico - TF, cerrado típico control - TC, RM-ANOVA - Repeated Measures-Analysis of variance, NMDS - Non-metric MultiDimensional Scaling.

\section{Introduction}

The savanna biome is distributed in almost all continents, covering ca. 23 million $\mathrm{km}^{2}$ (Uhlmann et al. 1998). More prevalent in tropical latitudes (Sarmiento 1984, Goedert et al. 2008), this biome is associated with a seasonal rainfall regime, with well-defined wet and dry periods (Frizzo et al. 2011). The most diverse savanna in the planet is located in South America, regionally known as Cerrado (Klink and Machado 2005, Cardoso et al. 2009). Covering ca. 2 million $\mathrm{km}^{2}$ (Schmidt et al. 2005), especially in the Brazilian Central Plateau, the Cerrado is a mosaic of vegetation physiognomies (Lima et al. 2009), i.e., a variety of open and dense forests, grasslands, wetlands and riparian vegetation (Ribeiro and Walter 2008). Because of its high diversity, endemism and human threat, the Cerrado is one of the 34 global hotspots for biodiversity conservation (Mittermeier et al. 2005).

A peculiar characteristic of savanna ecosystems is the presence of fire, which works as a significant structuring force. The relationship between savanna vegetation and fire is probably very old (million years; Silva et al. 2011), and shaped plant evolution (Pivello 2011). Through geological times, species evolved adaptations to cope with this distur- bance, including resistant structures (e.g., stems, leaves and roots) and strategies (e.g., fast sprouting, seed dormancy). Regrowth (sprouting) is an important mechanism, as many plants have adaptations to survive and quickly produce vegetative organs. They have root systems and suberized stems that effectively protect germination gems, allowing immediate sprouting after the fire (Scholes and Archer 1997, Hoffmann 2000). Resilience to fire is therefore high (Heringer and Jacques 2001), but many studies suggest that fire frequency and intensity modulate the structure of vegetation and determine physiognomies (Moreira 2000, Lima et al. 2009). In South America, high recurrence of fire, for example, may decrease the presence of trees, changing forested environments (i.e., cerrado típico) into more open formations (i.e., cerrado ralo) (Heringer and Jacques 2001). The absence of fire, conversely, favors the development of forest physiognomies (Lopes et al. 2009). The mosaic-type landscape of this savanna is greatly determined by spatial and temporal variations in fire disturbances, together with other local factors (e.g., herbivory, soil) (Silva et al. 2011).

Studies on community reassembly are necessary to reveal how fire disturbances induce variations in plant diversity (Bond and Keeley 2005), especially because human activities 
have changed fire regimes (i.e., suppression or intensification). Human-induced fires date back to 400,000 years ago in the African continent (Gowlett and Wrangham 2013), but in South America this interference probably started ca. 12,000 years ago (Pivello 2011). Post-industrial society, however, changed dramatically the natural fire regime in most savannas of the world. In South America, fire frequency and intensity is currently much higher than natural rates (INPE - Instituto Nacional de Pesquisas Espaciais 2018), causing significant perturbation to vegetation structure and biodiversity (Durigan and Ratter 2016). Although many studies have investigated this relationship (e.g., Scholes and Archer 1997, Bond and Keeley 2005, Archibald et al. 2009, Staver et al. 2011, Andela et al. 2017), little is known about immediate responses and short-term dynamics, i.e., small-scale successional patterns (monthly changes). Recovery dynamics and assemblage trajectory (i.e., convergence or divergence; Booth and Swanson 2002) have been poorly investigated, considering that studies usually compare samples collected at coarse scales, e.g., years or seasons (Soares et al. 2006, Lima et al. 2009, Lopes et al. 2009, Silva et al. 2011). However, the recovery process starts soon after the fire, and may cause rapid species deletions, substitutions and additions (Salles and Schiavini 2007, Silva et al. 2011). Three main mechanisms are responsible for community reassembly, which occur simultaneously: propagule invasion, seed bank, and regrowth of surviving individuals (Scholes and Archer 1997, Lima 2005). Another important question concerns whether composition, richness and abundance return to pre-disturbance levels over a year period, i.e., the common interval between fire events (dry seasons). This body of information is important to guide land use practices, management and conservation of savanna remnants, especially in South America, where urban and agriculture development have increased the incidence and intensity of fires (Silva et al. 2011), including catastrophic episodes.

In this context, we investigated short-term dynamics of two Cerrado physiognomies (tipico and ralo) in response to fire disturbance. The study was carried out in the Tocantins State, north Brazil, a region that still preserves large extensions of savanna vegetation, but which has been increasingly disturbed by human-induced fires. Over the course of a year, we monitored vegetation structure to investigate community reassembly in respect to (i) monthly changes in richness, density and composition, (ii) assemblage trajectory at local scales, and (iii) convergent/divergent trends in respect to the structure found in a preserved area (undisturbed).

\section{Material and methods}

\section{Study area}

The study was carried out in the Tocantins State, north Brazil, which holds the largest remnants of Cerrado vegetation in South America. Originally, the Cerrado covered 91\% of this State (Sano et al. 2008), and the vegetation remained relatively well preserved until recently, possibly because the region is distant from large urban centers (Sano et al. 2008).
This situation, however, changed rapidly during the last decade, as hydropower dams, mining and agribusiness activities (cattle, soy and eucalyptus) expanded across the region (Lapola et al. 2014, Ferreira et al. 2014, Lees et al. 2016). It has led to large-scale changes in land cover, fragmentation, and the incidence of several environmental disturbances, including fires.

The study was conducted in the Cerrado sensu stricto, a savanna formation composed of trees, shrubs and grasses. This vegetation is subdivided in two main physiognomies (Ribeiro and Walter 2008): cerrado típico (i.e., typical) and cerrado ralo (i.e., sparse). Both physiognomies are dominant features of the Brazilian Cerrado, and they differ in respect to the extent of tree coverage. Trees are more common in the cerrado típico (20 to $50 \%$ ), being less prevalent in the cerrado ralo (5 to $20 \%$ ), where grasses dominate. These differences are associated with fire regimes and edaphic conditions (Ribeiro and Walter 2008, Silva et al. 2011), which create a mosaic-like landscape with vegetation patches. Trees are not tall, usually shorter than $5 \mathrm{~m}$; grasses are also small-sized, forming bushes with short leaves ( $<50 \mathrm{~cm}$ height). Common tree species are Conarus, Eryhtroxylum and Handroanthus; among common shrubs are Annona, Byrsonima and Palicourea, while common herbs/grasses are Axonopus, Trachypogon, Mesosetum and Paspalum. Both physiognomies contain bromeliads and palm trees.

The study area is located in private land (São Judas Tadeu Farm), Porto Nacional municipality, Tocantins State $\left(10^{\circ} 48^{\prime} 09^{\prime \prime} \mathrm{S}\right.$ and $\left.48^{\circ} 25^{\prime} 28^{\prime} \mathrm{W}\right)$. The area has irregular slopes with the presence of valleys and plateaus, including other vegetation types, e.g., semi-deciduous dry forests (mata seca), flooded vegetation (vereda) and pastures (cattle raising). The soil is oxisol with the presence of rock fragments of different sizes. The climate is warm and seasonal, with rainy summers and dry winters, average annual rainfall of 1,500 $\mathrm{mm}$ concentrated between October and April. In mid-August 2010 (dry season), a large-scale fire burned part of the area (Figure 1A and D), spreading over ca. 100 hectares. All biomass contained in leaves and litter was consumed, remaining only coarse structures of woody species (e.g, suberized stems). According to local people, another burning occurred in 2007, three years before this study, when the area was substantially affected. The history of fire in the area is unknown, but we are aware of other large-scale fires during 2004 and 2006. In this sense, the area has been subjected to sequential fire disturbances over the years 2004, 2006, 2007 and 2010, probably with fires in precedent years.

It is important to state that the current fire regime in the Cerrado is different from ancient times (Pivello 2011), because human activities (both pre-historical and modern) have increased the frequency and intensity of burnings. Although recent studies indicate that fire frequency in savannas is declining (Andela et al. 2017), and others argue that fire suppression should be avoided to preserve natural ecological dynamics (Durigan and Ratter 2016), a high number of fire spots is the norm in South America (Pivello 2011). Human-induced fires are periodic and recurrent in the northern Cerrado, so 


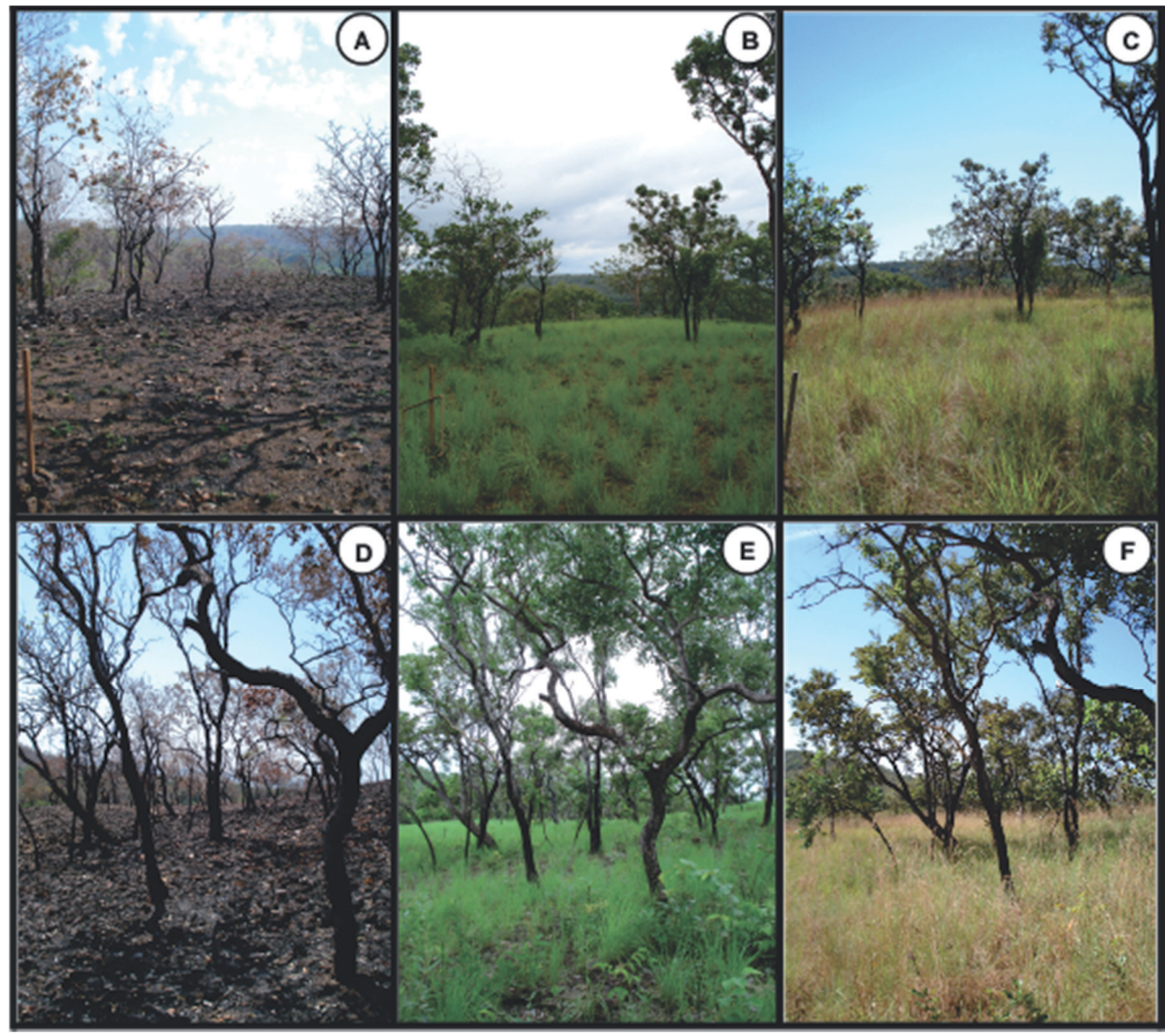

Figure 1. Plots monitored in the cerrado típico (bottom) and cerrado ralo (upper), one week (A and D, respectively), four months (B and $\mathrm{E})$ and 11 months after fire disturbance (C and F).

fire intensification has been the rule. In 2010 alone, for example, more than 120 thousand fire spots were recorded in the Tocantins State (INPE - Instituto Nacional de Pesquisas Espaciais 2018). The natural fire regime in this region is poorly known, but considering that some localities remain undisturbed for years, it is reasonable to suppose that natural fire frequency is not annual. In this context, the present research took place in a region disturbed by unnatural fires, with high rates and intensity.

\section{Data sampling}

A total of 30 permanent plots were established in the study area, 15 in the cerrado típico and 15 in the cerrado ralo. Within each vegetation type, 10 plots were allocated in the area disturbed by fire, and 5 in a preserved control area (undisturbed). The smaller number of control plots was due to the small size of the area undisturbed. We adopted the method of rectangular permanent plots (Felfili et al. 2005), each $5 \mathrm{~m}$ $\times 10 \mathrm{~m}$, spaced at least $50 \mathrm{~m}$ apart. The plots were distributed over an area of approximately 40 hectares.

Monitoring started one week after the fire and lasted for 11 months, from August 2010 to June 2011 (excluding January and February 2011). Plots disturbed by fire were surveyed monthly ( $n=9 /$ plot), while control plots were surveyed every two months $(\mathrm{n}=5 / \mathrm{plot})$. At each survey, we recorded the presence of all plants, including herbs, shrubs and trees. We also counted the number of individuals of each species, with the exception of small herbaceous plants $(<10 \mathrm{~cm})$, seedlings and clonal plants (i.e., sprouts and stems originated from another plant, whose existence and maintenance are not independent). When necessary, vegetative or reproductive organs were sampled for identification, without removing the individual. Plants were identified to the species level or to the lowest taxonomic category, using exsiccates deposited in the Herbário do Laboratório de Taxonomia Vegetal (HTO, Universidade Federal do Tocantins) and specialized literature. The classification system followed the Angiosperm Phylogeny Group - APGIII (Bremer et al. 2009).

\section{Data analysis}

We investigated temporal changes in vegetation structure of the cerrado típico $(\mathrm{TF}=$ disturbed by fire; $\mathrm{TC}=$ control $)$ and cerrado ralo $(\mathrm{RF}=$ disturbed by fire; $\mathrm{RC}=$ control $)$, concerning temporal trajectories of abundance, species richness and composition. Because we were looking for patterns of convergence and divergence between burned and control plots, analyses were conducted separately for each vegetation type (contrasts: TF vs. TC and RF vs. RC). 
To investigate patterns in total richness, we calculated rarefaction curves based on sampling effort (plots). In this case, sample order in the original matrix was randomized 500 times (Estimates 8.2; Colwell 2009). We also calculated richness $\left(\mathrm{spp} . / 50 \mathrm{~m}^{2}\right)$ and plant density (plants $\left./ 50 \mathrm{~m}^{2}\right)$ of each plot, and used repeated measures analysis of variance (RM-ANOVA) to test for differences in mean values over the months and between groups (fire vs. control). This analysis is indicated when samples have temporal autocorrelation, i.e., multiple observations of the same object (plots). Variables were transformed $(\log x+1)$ to meet parametric assumptions. We applied Tukey tests to compare means, and statistical significance implied $p<0.05$. This analysis was run in Statistica 7.0 (StatSoft, Inc. 2004).

Non-metric multidimensional scaling (NMDS) was used to investigate compositional changes over time, i.e., successional trajectories of each plot. This analysis was based on presence/absence data and Sørensen distance. We run the NMDS in the Past 1.75b software (Hammer et al. 2001). Finally, we compared temporal variations in species abundance ranks (relative abundance, \%) between disturbed vs. control groups. For this, we considered species that summed $80 \%$ of abundance in the undisturbed area (control plots pooled), and investigated temporal changes in their mean abundance in the plots affected by the fire, considering only months $1,3,5,9$ and 11

\section{Results}

\section{Plant diversity}

Over the study period, we obtained 14,922 plant records in the 30 monitored plots, which belonged to 170 taxa and 63 families (Supplementary Information 1). The most diverse families were Fabaceae (33 taxa), followed by Apocynaceae (9), Rubiaceae (9) and Bignoniaceae (8). Concerning the cer-
Table 1. Repeated measures ANOVA testing the effect of time (months) and disturbance regime (fire vs. control) on species richness and plant density, in plots monitored in the cerrado típico.

\begin{tabular}{lcrc}
\hline Attributes & GL & \multicolumn{1}{c}{ F } & P \\
\hline Taxon richness & & & \\
Disturbance & 1 & 0.0038 & 0.9518 \\
Time & 4 & 115.6669 & 0.0000 \\
Disturbance*Time & 4 & 51.9590 & 0.0000 \\
\hline Plant density & & & \\
Disturbance & 1 & 0.0718 & 0.7929 \\
Time & 4 & 133.4702 & 0.0000 \\
Disturbance*Time & 4 & 53.7925 & 0.0000 \\
\hline
\end{tabular}

rado típico, we recorded 135 taxa in the disturbed plots (TF), and 76 in the control (TC); regarding the cerrado ralo, we recorded 81 taxa in the disturbed plots (RF), and 41 in the control (TC). Rarefaction curves showed that, controlling for sampling effort, disturbed plots have higher species richness in both physiognomies (Figure 2). All curves tended to stabilize after a rapid initial accumulation.

\section{Cerrado típico dynamics}

Local species richness averaged on 24.5 taxa $/ 50 \mathrm{~m}^{2}$ in the $\mathrm{TF}$, and $21.7 \mathrm{taxa} / 50 \mathrm{~m}^{2}$ in the TC. Overall, species richness in TF plots varied over the months, with low values after the disturbance, a continuous increase until the fifth month, and a tendency to stabilization after the eighth month (Figure 3A). The last months showed values similar to TC plots. The RMANOVA revealed significant interaction between time and disturbance $(\mathrm{F}=51.96, \mathrm{p}<0.00001$; Table 1$)$, indicating that species richness differed over time, but with different patterns between burned and control plots. In this case, TF plots in the first two months differed significantly from other months of the same treatment (Tukey; $p<0.05$ ). In addition, TF plots in
Figure 2. Rarefaction curves based on sampling effort, considering plots monitored in the cerrado típico disturbed by fire (TF) and control (TC), and cerrado ralo disturbed by fire (RF) and control (RC). Curves were built after 500 randomizations of the original matrix.

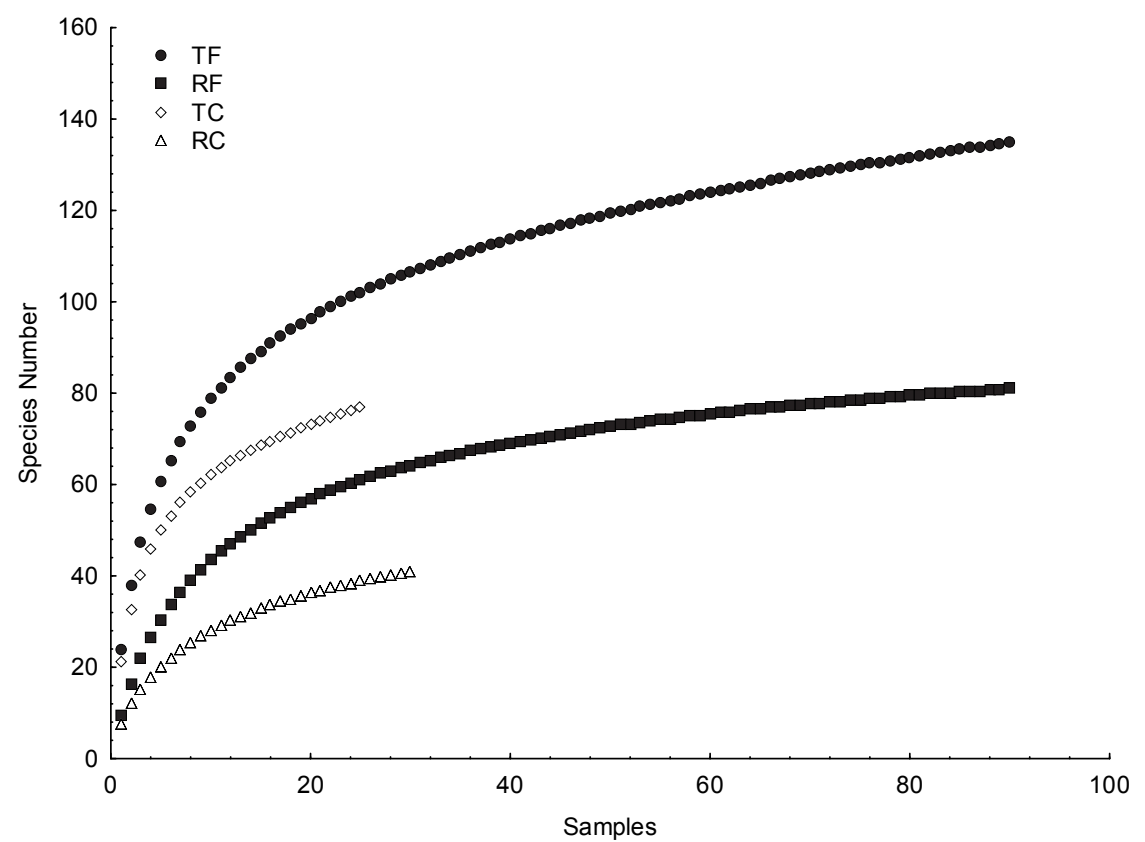



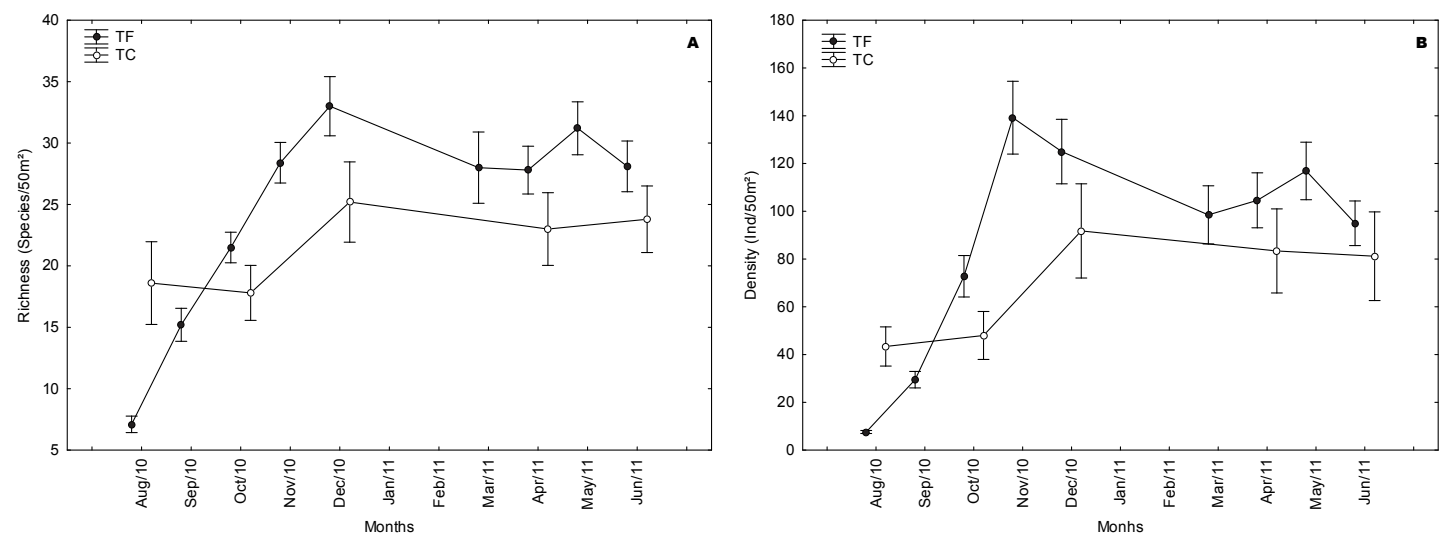

Figure 3. Temporal variations in species richness (A) and plant density (B) in the cerrado típico, considering plots disturbed by fire (TF) and control (TC). Values are mean \pm standard error.
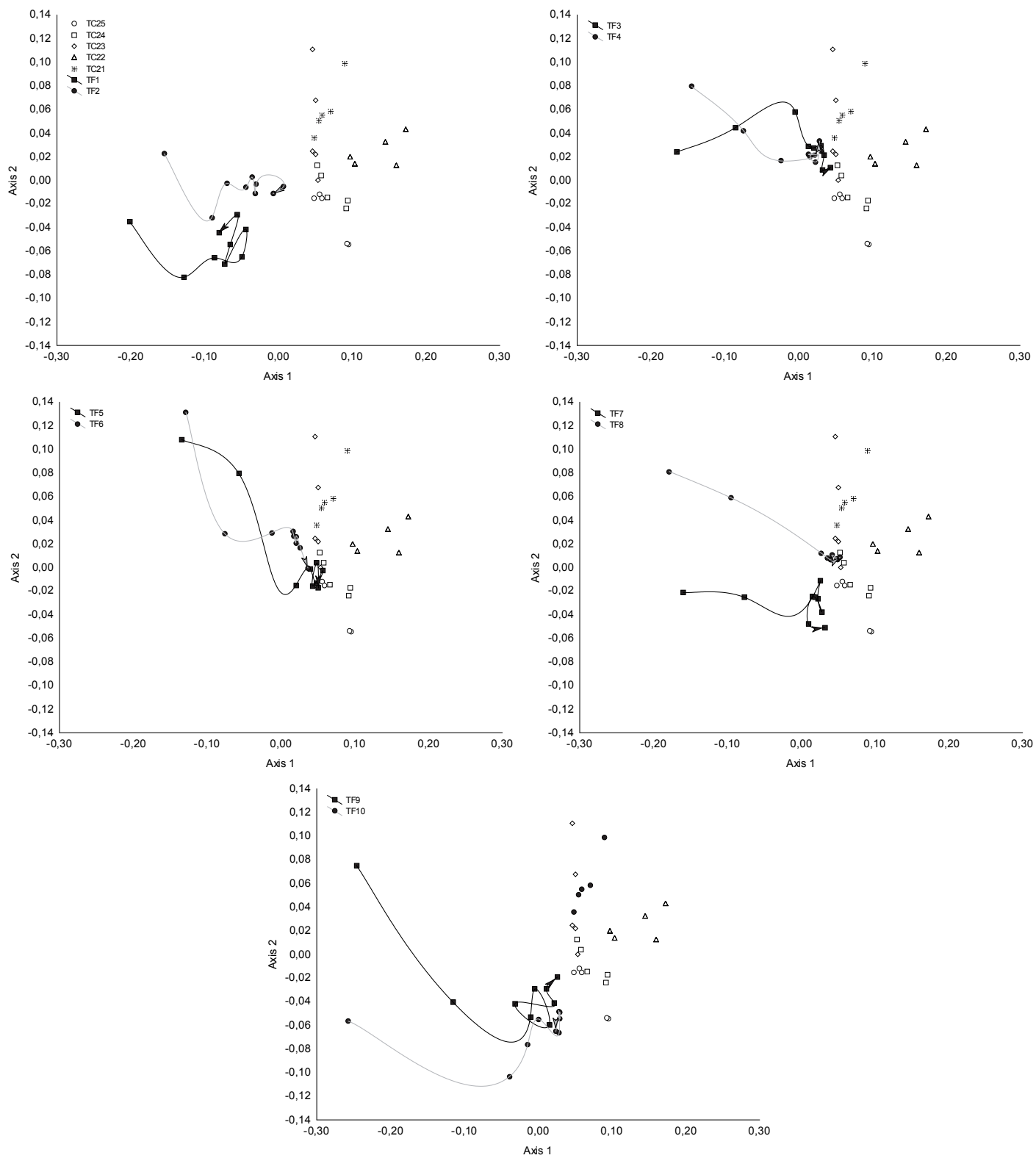

Figure 4. Non-metric Multidimensional Scaling analysis (NMDS) revealing compositional variation in TF (1 to 10) and TC plots (21 to 25). The line connecting dots indicates the temporal trajectory, and the arrow indicates the last month. 
the first month differed significantly from all TC plots, with the exception of the first month. There was no significant difference among TC plots over time.

Plant density averaged on 87.7 plants $/ 50 \mathrm{~m}^{2}$ in the TF, and 69.6 plants $/ 50 \mathrm{~m}^{2}$ in the TC. Plant density in the TF showed considerable variation over months, with low values soon after the fire, a progressive increase until the fourth month, and tendency to converge to TC plots (Figure 3B). The RMANOVA revealed significant interaction between time and disturbance $(\mathrm{F}=53.79, \mathrm{p}<0.00001$; Table 1$)$. In this case, TF plots in the first two months showed lower values when compared to other months of the same treatment (Tukey; $\mathrm{p}<$ 0.05). Furthermore, TF plots in the first month differed significantly from all TC plots, with the exception of the first month. There was no significant difference among TC plots over time.

The NMDS ordination (stress $=0.257$ ) revealed variation in species composition related to spatial gradients (among
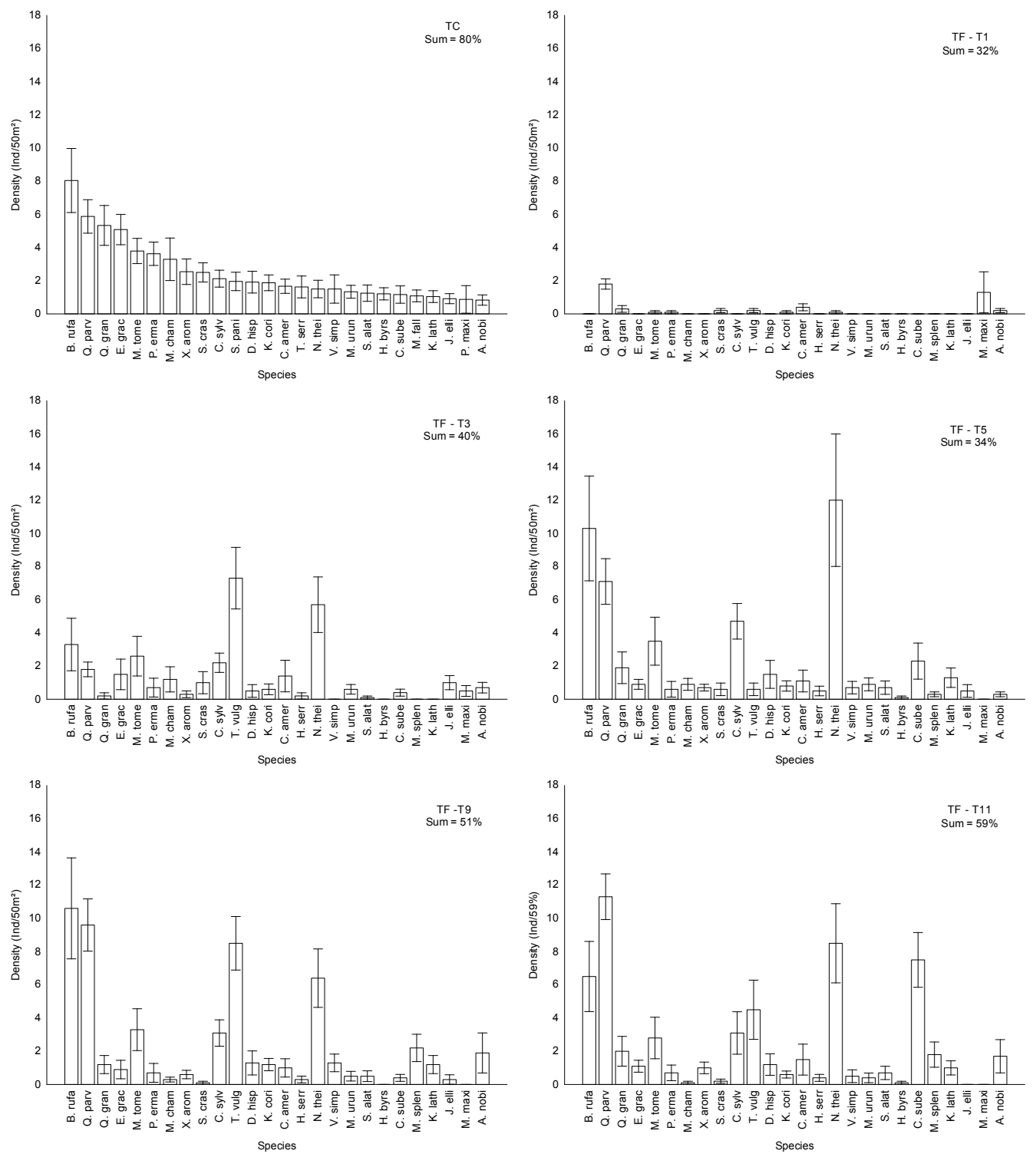

Figure 5. Species abundance rank in TC plots considering species that summed $80 \%$ of total abundance, and temporal variation in their abundance in TF plots (months 1, 3, 5, 9 and 11). Sum = contribution (\%) of these species to total abundance in each month.

plots), months and disturbance regime (Figure 4). Overall, there were different compositional patterns between TF and $\mathrm{TC}$, since TC plots were grouped together, with minor variation among plots and months. In the TF, on the other hand, there was greater variation within-plots, revealing strong changes in the first months after fire, and lower variation after the third month (Fig. 4). In addition, we observed variation among-plots, since they started and ended with different composition, following different temporal trajectories. However, all TF plots tended to converge to TC plots after a few months.

We observed temporal changes in species dominance in TF plots, especially in the first months after the fire (Fig. 5). The abundance rank differed between disturbed and control plots, but some of the main species in TC became abundant in TF during the last months (Fig. 5). It is worth noting that their contribution to total abundance (\%) increased over time, summing 59\% in the last month (Fig. 5).
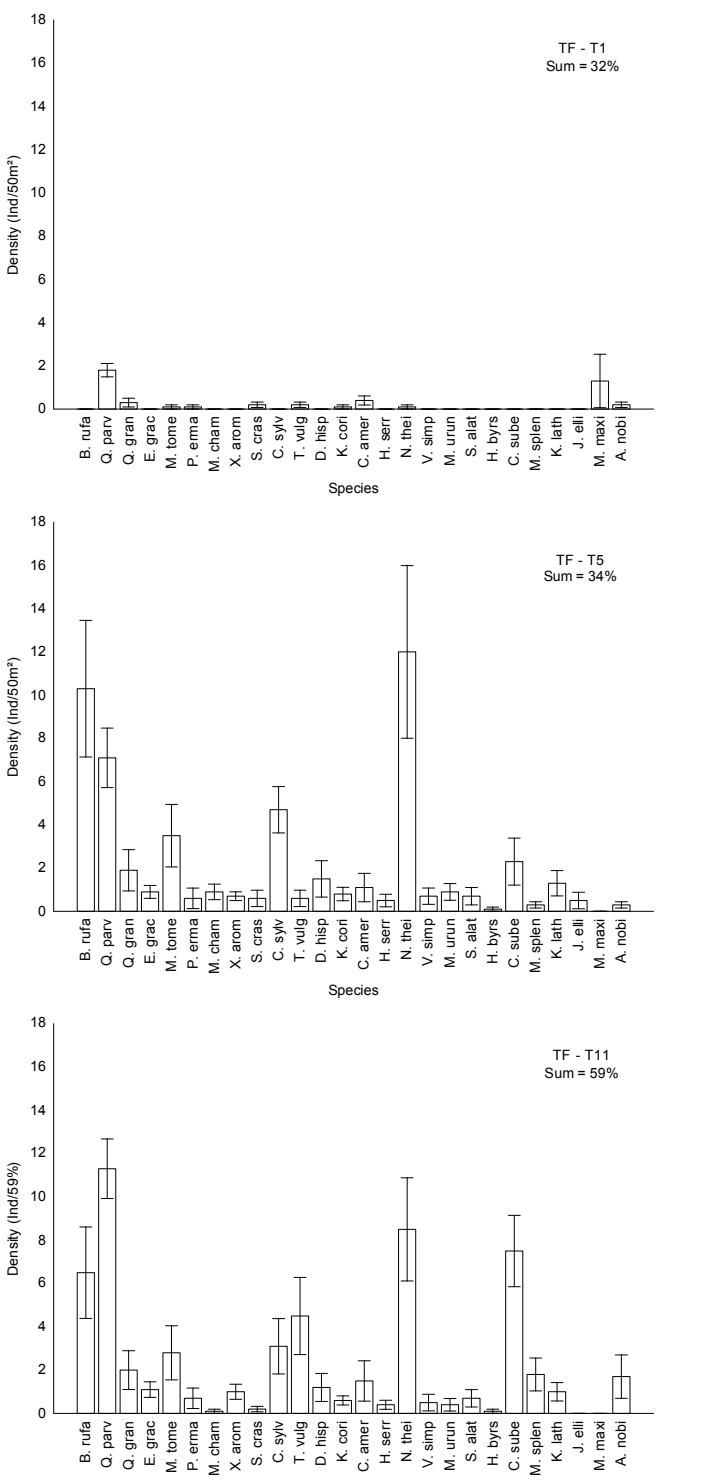


\section{Cerrado ralo dynamics}

Local species richness averaged on $9.5 \operatorname{taxa} / 50 \mathrm{~m}^{2}$ in the $\mathrm{RF}$, and 7.7 taxa $/ 50 \mathrm{~m}^{2}$ in the RC. Overall, species richness in RF plots varied over time, with low values after the disturbance, a continuous increase until the fourth month, followed by stabilization (Figure 6A). The last months showed values similar to TC plots. The RM-ANOVA revealed significant interaction between time and disturbance $(\mathrm{F}=7.92$, $\mathrm{p}<0.00001$; Table 2). In this case, RF plots in the first two months differed significantly from other months in both disturbed and control treatments (Tukey; $p<0.05$ ), except for the first month of RF, which did not differ from the first two months of RC. Considering only RC plots, the first two months differed from the others.

Plant density averaged on 21.6 plants $/ 50 \mathrm{~m}^{2}$ in the RF, and 20.3 plants $/ 50 \mathrm{~m}^{2}$ in the RC. Both groups showed considerable variation in plant density over time. In RF plots, we observed low density soon after the fire, a progressive increase until the fourth month, followed by convergence to RC plots (Figure 6B). RC plots also showed seasonal variation, with high values after the fifth month. The RM-ANOVA revealed significant interaction between time and disturbance $(\mathrm{F}=$ 4.57, $\mathrm{p}<0.0012$; Table 2). In this case, RF plots in the first month differed from other RF months, and from the last four RC months (Tukey; $\mathrm{p}<0.05$ ). Furthermore, RC plots in the first month differed from other months of the same treatment.

The NMDS ordination (stress $=0.327$ ) revealed variation in species composition related to spatial gradients (among plots), months and disturbance regime (Fig. 7). Overall, there were different composition patterns between RF and $\mathrm{RC}$ plots; these last were grouped together, but showed some variation among plots and months. In the RF, on the other hand, there was greater variation within-plots, revealing very heterogeneous trajectories over time (Fig. 7). These plots had dissimilar composition in the first month, and showed no indication of convergence to RC plots in the last month.

We observed strong temporal changes in species dominance in RF plots, with little similarity to the abundance rank observed in RC plots (Fig. 8). In addition, these species con-

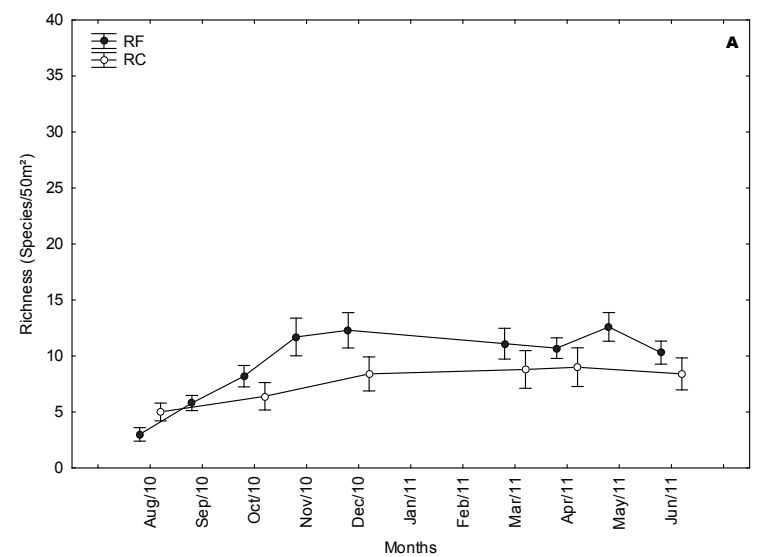

Table 2. Repeated measures ANOVA testing the effect of time (months) and disturbance regime (fire vs. control) on species richness and plant density, in plots monitored in the cerrado ralo.

\begin{tabular}{lcrc}
\hline Attributes & GL & F & P \\
\hline Taxon richness & & & \\
Disturbance & 1 & 0.3686 & 0.5542 \\
Time & 5 & 40.5742 & 0.0000 \\
Disturbance*Time & 5 & 7.9157 & 0.0000 \\
Plant density & & & \\
Disturbance & 1 & 0.5384 & 0.4761 \\
Time & 5 & 48.3224 & 0.0000 \\
Disturbance*Time & 5 & 4.5727 & 0.0012 \\
\hline
\end{tabular}

tributed little to total abundance in all months, especially in the last (17\%), indicating lack of convergence between disturbed and control plots (Fig. 8).

\section{Discussion}

Our study investigated the response of savanna vegetation to fire disturbance, describing short-term dynamics of community reassembly in two physiognomies of the South American Cerrado (cerrado típico and ralo). The survey was conducted on a monthly basis over a year, a grain scale appropriate to reveal immediate responses and successional dynamics. Other studies have employed longer time scales (e.g., Nappo et al. 2005, Soares et al. 2006, Rodrigues et al. 2007), usually limited to compare before and after samples. At the small scale, we were able to see that fire significantly affected plant diversity in both physiognomies, but community reassembling was fast. After a few months, species richness and plant density reached levels observed in undisturbed sites, and composition in the woody formation (típico) tended to converge to control plots. Savanna vegetation is resilient to fire, and assemblages may roughly converge to their initial conditions after the disturbance (Nunes et al. 2002). However, local assemblages showed heterogeneous successional trajectories and composition, especially in the open formation (ralo), indicating stochastic reassembling. In addi-

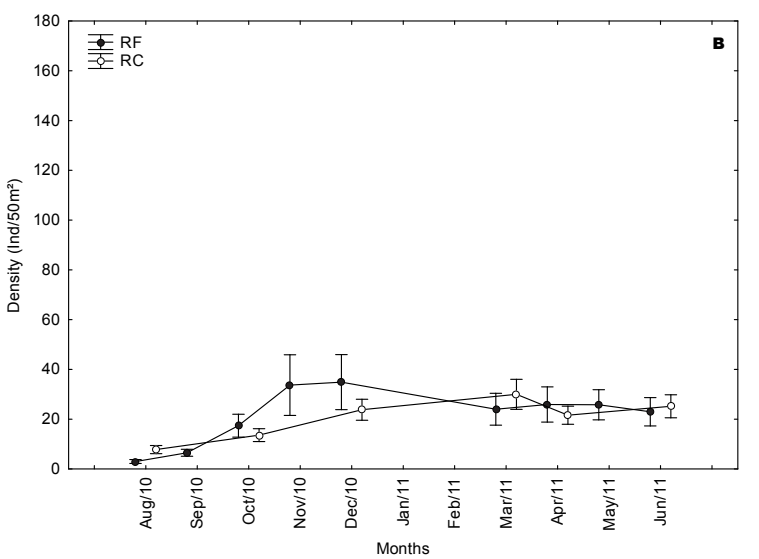

Figure 6. Temporal variations in species richness (A) and plant density (B) in the cerrado ralo, considering plots disturbed by fire (RF) and control $(\mathrm{RC})$. Dots and whiskers are mean \pm standard error, respectively. 

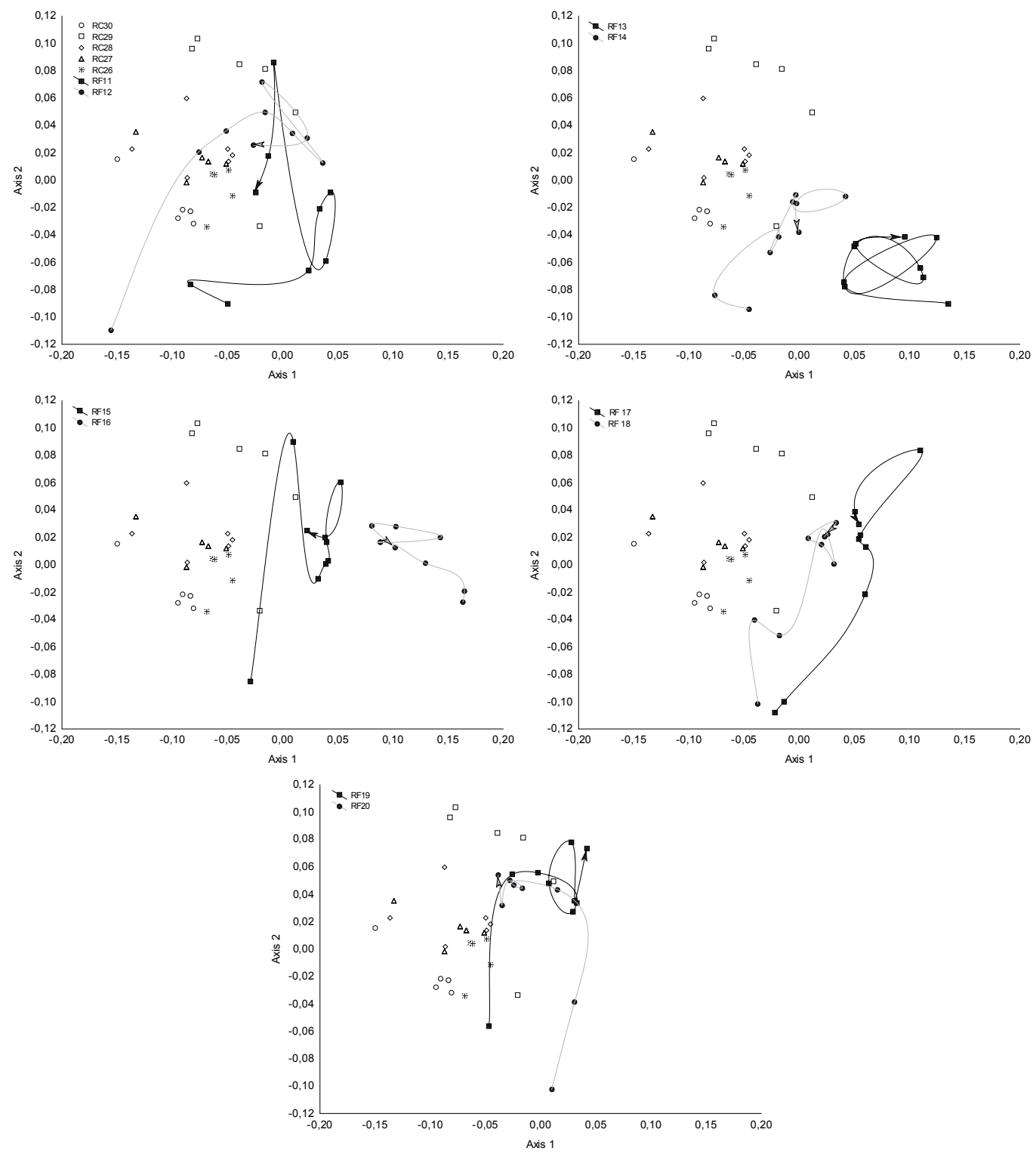

Figure 7. Non-metric Multidimensional Scaling analysis (NMDS) revealing compositional variation in RF (26 to 30 ) and RC plots (11 to 20). The line connecting dots indicates the temporal trajectory, and the arrow indicates the last month.

tion, higher values of richness and density in disturbed plots, together with heterogeneous abundance ranks, indicate that community development will continue. Therefore, although vegetation diversity (i.e., richness and abundance) was able to recover in the course of a year, some attributes (i.e., composition, species rank) indicate that fire disturbances change the structure of local assemblages, with longer-lasting effects. In the absence of new disturbances, changes in vegetation structure are expected via species replacement, new invasions and the strengthening of competitive interactions.

Recovery patterns were observed mainly in the cerrado típico. Richness and density peaked four months after the fire and tended to stabilize. The progressive increase in species richness and plant density is strong indication of community reassembling (Chazdon 2012). In addition, plant composition tended to converge to the structure found in control plots. Different processes determine the response of plant com- munities to disturbances, including seed storage, invasion and immediate regrowth of surviving plants (Kammesheidt 1999, Álvarez-Yépiz et al. 2008, Chazdon 2012). In savanna ecosystems, plant regrowth must play a central role. It was commonly observed in our plots, especially during the first months. Several adaptations grant resistance against fire, such as suberized stems, protected gems and gemiferous roots (Hoffmann 1998). These characteristics allow resident individuals to survive and regrow, even when significant aerial biomass is removed. Regrowth is probably a strong mechanism of resilience and inertia in woody formations, since surviving trees and bushes lead succession to pre-disturbance states in a relatively short period. Each plot, however, showed different temporal trajectories with heterogeneous species ranks, probably because different factors affect plant succession at the local scale. It may include, for example, local disturbances (Connell and Slatyer 1977, Chazdon 2012), initial 

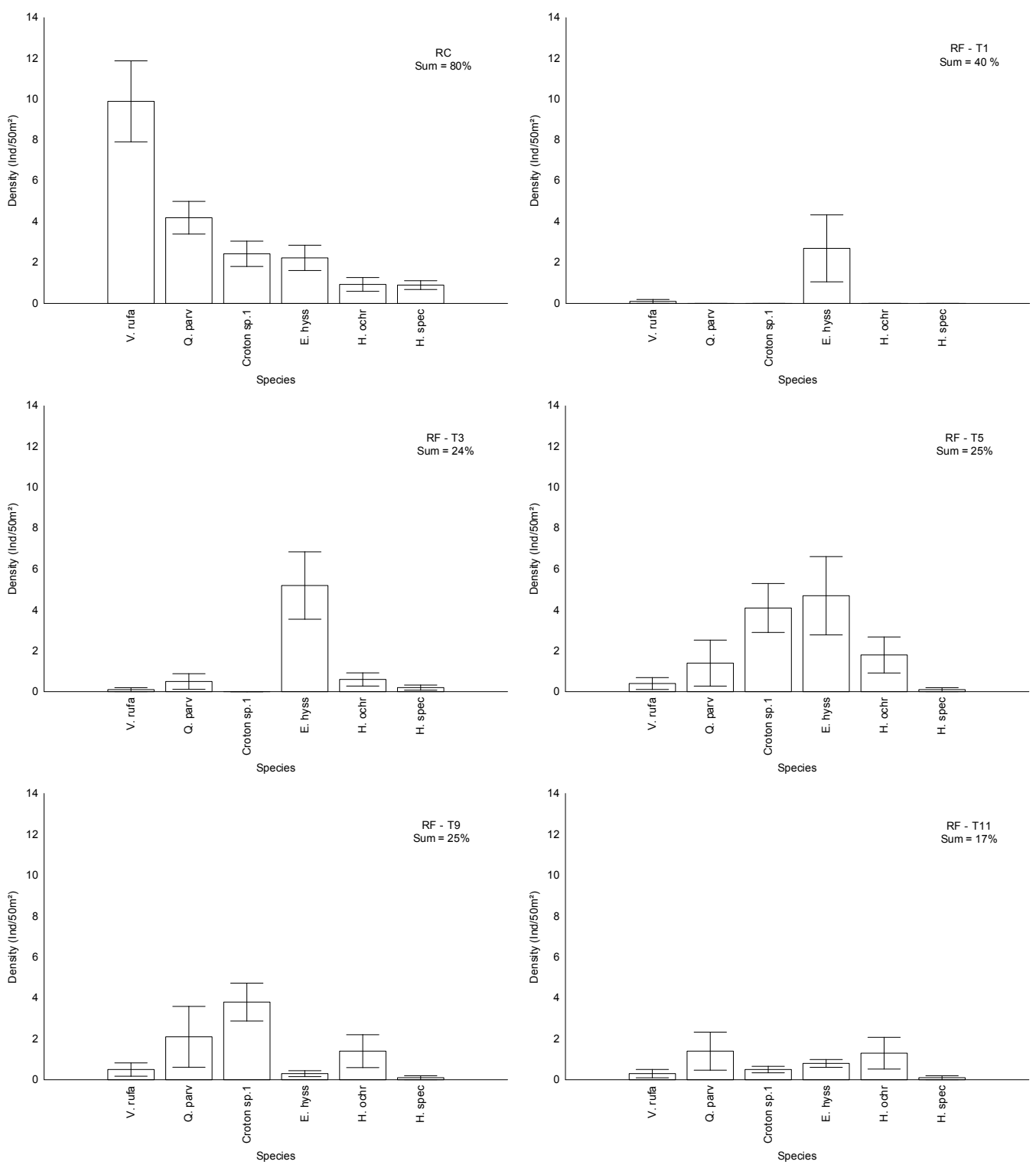

Figure 8. Species abundance rank in RC plots considering only species that summed $80 \%$ of total abundance, and temporal variation in their abundance in RF plots (months 1, 3, 5, 9 and 11). Sum = contribution (\%) of these species to total abundance in each month.

composition and invasion sequence (Drake 1990, Fukami et al. 2005, Ejrnaes et al. 2006), stochastic invasion and extinction (Chase 2003, Tilman 2004) and local biotic interactions (Fargione et al. 2003, Lortie et al. 2004). The stochastic action of these processes may cause variation among plots, but surviving plants likely play a significant role inducing inertia and convergent patterns in forested formations.

In the cerrado ralo, we also observed convergent patterns for species richness and abundance. However, plot composition showed very heterogeneous trajectories, with no indication of convergence between disturbed and control areas. Species abundance ranks also revealed significant dissimilarity in species composition, indicating strong divergence at the end of the study. Two species dominated disturbed plots (Erythroxylum suberosum A.St.-Hil. and Croton sp. 1), but they were rare in control plots. It should be noted that in the cerrado ralo, where the proportion of woody species is smaller, plant biomass is significantly destroyed by fire. The removal of dominant species may release resources, light and space for invaders (Hoffmann 1996, Davis et al. 2000, Hoffmann 2000, Frizzo et al. 2011). Community reassembly would depend more on dispersal dynamics than on plant regrowth, fueling stochastic processes via invasion and colonization. Temporal changes in composition are strongly influenced by invasion sequence and priority effects (Booth and Swanton 2002, Fukami et al. 2005), creating a mosaic spatial structure. Therefore, reassembly dynamics in the cerrado ralo is different from the cerrado típico probably because different mechanisms prevail, i.e., seed dispersal and regrowth, respectively.

Ecological communities are highly dynamic and historically built (Booth and Swanton 2002, Chase 2003, Tilman 2004). Community assembly follows complex and dynamic routes that include purely stochastic processes (i.e., disper- 
sion/invasion; Drake 1990, Lortie et al. 2004, Hubbell 2006) and more deterministic relationships with environmental filters and biotic interactions (Keddy 1992, Bruno et al. 2003, $\mathrm{Kraft}$ et al. 2015). However, community development in savanna ecosystems may follow other assembly rules, such as plant regrowth after fire disturbance. Regrowth is common among savanna species (Hoffmann 1998, Nunes et al. 2002), especially because natural fires do not kill most plant individuals. This process confers high resilience, inertia and determinism to vegetation structure, allowing fast development and convergence to undisturbed states - a pattern observed in the cerrado típico vegetation. Much emphasis has been given to seed dispersal as a chief mechanism during initial succession (Drake 1990, Booth and Swanton 2002, Fukami et al. 2005), but community assembly models in savanna ecosystems must include regrowth as an important mechanism restructuring plant diversity after disturbance by fire. However, in herbaceous physiognomies, where many species lack protective structures (Hoffmann, 1999; Kennard et al. 2002), regrowth dynamics may be less important. The same is expected when fires have lethal effects (i.e., too intense and frequent), compromising the regrowth of fire-adapted species in both forested and open physiognomies. In these cases, propagule invasion would be a main driver behind community development, leading to multiple non-convergent trajectories (e.g., Booth and Swanton 2002, Fukami et al. 2005). In this sense, community assembly models for savanna ecosystems must consider that response to fire will depend on both fire regime and vegetation physiognomy, which trigger different assembly mechanisms.

The Cerrado sensu stricto, a major component of the savanna biome, is a system ruled by natural fires. However, human activities have changed the natural fire regime, and much discussion have pondered the detrimental effects of fire intensification or suppression on biodiversity. Recent studies, for example, emphasize the need for consistency fire policies, especially because fire suppression in some areas has transformed savanna vegetation into forests, causing changes in biodiversity patterns and ecosystem functions (Durigan and Ratter 2016). However, Cerrado vegetation has been subjected mainly to fire intensification (i.e., intensity and frequency), and many natural areas are disturbed at unnatural high rates (Silva et al. 2011, INPE - Instituto Nacional de Pesquisas Espaciais 2018), with negative effects on biodiversity (Miranda et al. 2002, Pivello 2011, Silva et al. 2011). To implement correct management practices, conservation policies will need information about natural fire regimes and the effects of human-induced fires on savanna vegetation. This information will enable the establishment of optimal fire frequencies, the best moment to induce controlled fires, or the implementation of fire suppression programs in protected and unprotected areas (e.g., van Wilgen et al. 2004, Govender et al. 2006, Silva et al. 2011, Valkó et al. 2014, 2018). Attributes of the natural fire regime remain poorly known in the South American savanna, but diversity is apparently maximized when disturbances occur at 3-year intervals (Pivello and Coutinho 1992, Silva et al. 2011), creating a balance between recovery, dominance and invasion. The study area remained undisturbed for 3 years (between 2007 and 2010), so plants had considerable time to accumulate energy reserves, protective structures and seed banks. It may explain the rapid reassembling of species in both physiognomies. Future studies must investigate the effect of recurrent fires (i.e., annual) on community development.

\section{References}

Álvarez-Yépiz, J.C., A. Martínez-Yrízar, A. Búrquez and C. Lindquist. 2008. Variation in vegetation structure and soil properties related to land use history of old-growth and secondary tropical dry forests in northwestern Mexico. Forest Ecol. Manag. 256:355-366

Andela, N., D.C. Morton, L. Giglio, Y. Chen, G.R. van der Werf, P.S. Kasibhatla, R.S. DeFries, G.J. Collatz, S. Hantson, S. Kloster, D. Bachelet, M. Forrest, G. Lasslop, F. Li, S. Mangeon, J.R. Melton, C. Yue and J.T. Randerson. 2017. A human-driven decline in global burned área. Science 356:1356-1362.

Archibald, S., D.P. Roy, B.W. van Wilgen and R.J. Scholes. 2009. What limits fire? An examination of drivers of burnt area in Southern Africa. Glob Change Biol. 15:613-630

Bond, W.J. and J.E. Keeley. 2005. Fire as a global 'herbivore': the ecology and evolution of flammable ecosystems. Trends Ecol. Evol. 20(7):387-394.

Booth, B.D. and C.J. Swanton. 2002. Assembly theory applied to weed communities. Weed Sci. 50:2-13.

Bremer, B., K. Bremer and M. Chase. 2009. An update of the Angiosperm Phylogeny Group classification for the orders and families of flowering plants: APG III. Bot. J. Linn. Soc. 181:120 .

Bruno, J.F., J.J. Stachowicz and M.D. Bertness. 2003. Inclusion of facilitation into ecological theory. Trends Ecol. Evol. 18(3):119125.

Cardoso, E., M.I.C. Moreno, E.M. Bruna and H.L. Vasconcelos. 2009. Mudanças fitofisionômicas no Cerrado: 18 anos de sucessão ecológica na estação ecológica do Panga, Uberlândia. Caminhos de Geografia, Uberlândia. 10(32):254-268.

Chase, J.M. 2003. Community assembly: when should history matter? Oecologia 136:489-498

Chazdon, R. 2012. Regeneração de florestas tropicais. Cienc. Nat. 7(3):195-218

Colwell R.K. 2009. EstimateS: statistical estimation of species richness and shared species from samples. Version 8.2. User's guide and application published at: http://purl.oclc.org/estimates.

Connell, J.H. and R.O. Slatyer. 1977. Mechanisms of succession in natural communities and their role in community stability and organization. Am Nat. 111:1119-1144.

Davis, M.A., J.P. Grime and K. Thompson. 2000. Fluctuating resources in plant communities: a general theory of invisibility. $J$. Ecol. 88:528-534.

Drake, J.A. 1990. Communities as assembled structures: do rules govern pattern? Trends Ecol. Evol. 5(5):159-164.

Durigan, G. and J.A. Ratter. 2016. The need for a consistent fire policy for Cerrado conservation. J. Appl. Ecol. 53:11-15

Ejrnaes, R., H.H. Bruun and B.J. Graae. 2006. Community assembly in experimental grasslands: suitable environment or timely arrival? Ecology 87(5):1225-1233.

Fargione, J., C.S. Brown and D. Tilman. 2003. Community assembly and invasion: An experimental test of neutral versus niche processes. Proc. Natl. Acad. Sci. USA 100(15):8916-8920. 
Felfili, J.M., F.A. Carvalho and R.F. Haidar. 2005. Manual para o monitoramento de parcelas permanentes nos biomas cerrado e pantanal - Brasília: Universidade de Brasília, Departamento de Engenharia Florestal.

Ferreira, J., L.E.O.C. Aragão, J. Barlow, P. Barreto, E. Berenguer, M. Bustamante, T.A. Gardner, A.C. Lees, A. Lima, J. Louzada, R. Pardini, L. Parry, C.A. Peres, P.S. Pompeu, M. Tabarelli and J. Zuanon. 2014. Brazil's environmental leadership at risk. Science 346:706-707.

Frizzo, T.L.M., C. Bonizário, M.P. Borges and H.L. Vasconcelos. 2011. Revisão dos efeitos do fogo sobre a fauna de formações savânicas do Brasil. Oecologia Australis 15(2):365-379.

Fukami, T., T.M. Bezemer, S.R. Mortimer and W.H. van der Putten 2005. Species divergence and trait convergence in experimental plant community assembly. Ecol. Lett. 8(12):1283-1290.

Goedert, W.J., E. Wagner and A.O. Barcellos. 2008. Savanas Tropicais: dimensão, histórico e perspectiva. In: Faleiro, F.G and A.L. Farias Neto (eds.), Savanas: desafios e estratégias para o equilíbrio entre sociedade, agronegócio e recursos naturais. EMBRAPA Cerrados, Planaltina. pp. 48-77.

Govender, N., W.S.W. Trollope and B.W. van Wilgen. 2006. The effect of fire season, fire frequency, rainfall and management on fire intensity in savanna vegetation in South Africa. J. Appl. Ecol. 43(4):748-758.

Gowlett, J.A.J and R.W. Wrangham. 2013. Earliest fire in Africa: towards the convergence of archaeological evidence and the cooking hypothesis. Azania 48(1):5-30.

Hammer, Q., D.A.T. Harper and P.D. Ryan. 2001. Past: Paleontologia Statistics software package for education and data analysis. Paleontologia Electronica 4(1):1-9.

Heringer, I. and A.V.A. Jacques. 2001. Adaptação das plantas ao fogo: enfoque na transição floresta - campo. Cienc. Rural. 31(6): 1085-1090.

Hoffmann, W.A. 1996. The effects of fire and cover on seedling establishment in a neotropical savanna. J. Ecol. 84(3):383-393.

Hoffmann, W.A. 1998. Post-burn reproduction of woody plants in a neotropical savanna: the relative importance of sexual and vegetative reproduction. J. Appl. Ecol. 35(3):422-433.

Hoffmann, W.A. 1999. Fire and population dynamics of woody plants in a neotropical savanna: matrix model projections. Ecology 80(4):1354-1369.

Hoffmann, W.A. 2000. A. Post-establishment seedling success in the brazilian Cerrado: a comparison of savanna and forest species. Biotropica 32(1):62-69.

Hubbell, S.P. 2006. Neutral theory and the evolution of ecological equivalence. Ecology 87(6):1387-1398.

INPE - Instituto Nacional de Pesquisas Espaciais, 2018. Portal do Monitoramento de Queimadas e Incêndios. Available from http://www.inpe.br/queimadas. Accessed 26 March 2018.

Kammesheidt, L. 1999. Forest recovery by root suckers and aboveground sprouts after slash-and-burn agriculture, fire and logging in Paraguay and Venezuela. J. Trop. Ecol. 15(02):143-157.

Keddy, P.A. 1992. Assembly and response rules: two goals for predictive community ecology. J. Veg. Sci. 3:157-164.

Kennard, D.K., K. Gould, F.E. Putz, T.S. Fredericksen and F. Morales 2002. Effect of disturbance intensity on regeneration mechanisms in a tropical dry forest. Forest Ecol. Manag. 162:197-208.

Klink, C.A. and R.B.A. Machado. 2005. Conservação do Cerrado brasileiro. Megadiversidade 1(1):147-145.

Kraft, N.J.B., P.B. Adler, O. Godoy, E.C. James, S. Fuller and J.M Levine. 2015. Community assembly, coexistence and the environmental filtering metaphor. Funct. Ecol. 29:592-599.
Lapola, D.M., L.A. Martinelli, C.A. Peres, J.P.H.B. Ometto, M.E. Ferreira, C.A. Nobre, A.P.D. Aguiar, M.M.C.L Bustamante, M.F. Cardoso, M.H. Costa, C.A. Joly, C.C. Leite, P. Moutinho, G. Sampaio, B.B.N. Strassburg and I.C.G. Vieira. 2014. Pervasive transition of the Brazilian land-use system. Nat. Clim. Change $4: 27-35$.

Lees, A.C., C.A. Peres, P.M. Fearnside, M. Schneider and J.A.S Zuanon. 2016. Hydropower and the future of Amazonian biodiversity. Biodivers. Conserv. 25(3):451-466.

Lima, R.A.F. 2005. Estrutura e regeneração de clareiras em Florestas Pluviais Tropicais. Braz. J. Bot. 28(4):651-670.

Lima, E.S., H.S. Lima and J.A. Ratter. 2009. Mudanças pós-fogo na estrutura e composição da vegetação lenhosa, em um Cerrado mesotrófico, no período de cinco anos (1997-2002) em Nova Xavantina - MT. Cerne 15(4):468-480.

Lopes, S.F., V.S. Vale and I. Schiavini. 2009. Efeito de queimadas sobre a estrutura e composição da comunidade vegetal lenhosa do Cerrado sentido restrito em Caldas Novas, GO. Rev. Árvore 33(4):695-704

Lortie, C.J., R.W. Brooker, P. Choler, Z. Kikvidze, R. Michalet, F.I Pugnaire. and R.M. Callaway. 2004. Rethinking plant community theory. Oikos 107 (2):433-438

Miranda, H.S., M.M.C. Bustamante and A.C. Miranda. 2002. The fire factor. In: Oliveira, P.S. and Marquis, R.J. (eds.), The Cerrados of Brazil: Ecology and Natural History of a Neotropical Savanna. Columbia University Press. pp. 51-68.

Mittermeier, R.A., P.R. Gil, M. Hoffmann, J. Pilgrim, T. Brooks, C.G. Mittermeier, J. Lamoreaux and G.A.B. Fonseca. 2005. Hotspots Revisited: Earth's Biologically Richest and Most Endangered Terrestrial Ecoregions. Conservation International, New York.

Moreira, A.G. 2000. Effects of fire protection on savanna structure in Central Brazil. J. Biogeogr. 27:1021-1029.

Nappo, M.E., J.J. Griffith, S.V. Martins, P.M. Júnior, A.L. Souza and A.T. Oliveira-Filho. 2005. Diametric struture dynamics for tree and shrub natural regeneration understory within pure stands of Mimosa scabrella Bentham. planted on a mined-out site at Poços de Caldas, Minas Gerais state. Rev. Árvore 29(1):35-46.

Nunes, R.V., M.C. Silva-Júnior, J.M. Felfili and B.M.T. Walter. 2002. Intervalos de classe para abundância, dominância e freqüência do componente lenhoso do cerrado sentido restrito no Distrito Federal. Rev. Árvore 26(2):173-182.

Pivello, V.R. and L.M. Coutinho. 1992. Transfer of macronutrients to the atmosphere during experimental burnings in an open cerrado (Brazilian savanna). J. Trop. Ecol. 8:487-497.

Pivello, V.R. 2011. The use of fire in the cerrado and amazonian rainforests of Brazil: past and present. Fire Ecol. 7(1):24-39.

Ribeiro, J.F. and B.M.T. Walter. 2008. As Principais Fitofisionomias do Bioma Cerrado. In: Sano S.M., S.P. Almeida and J.F. Ribeiro. (eds.), Cerrado: ecologia e flora. Vol. 1. Embrapa Informação Tecnológica, Brasília. pp. 153-212.

Rodrigues, G.B., K.L. Maltoni and A.M.R. Cassiolato. 2007 Dinâmica da regeneração do subsolo de áreas degradadas dentro do bioma Cerrado. AGRIAMBI 11:1, 73-80.

Salles, J.C. and I. Schiavini. 2007. Estrutura e composição do estrato de regeneração em um fragmento florestal urbano: implicações para a dinâmica e a conservação da comunidade arbórea. Acta Bot. Bras. 21(1):223-233.

Sano, E.E., R. Rosa, J.L.S. Brito and L.G. Ferreira. 2008. Mapeamento semidetalhado do uso da terra do Bioma Cerrado. PAB - Pesquisa Agropecuária Brasileira 43(1):153-156.

Sarmiento, G. 1984. The Ecology of Neotropical Savannas. Harvard University Press, Cambridge. 
Schmidt, I.B., A.B. Sampaio and E.F. Borghetti. 2005. Efeitos da época de queima sobre a reprodução sexuada e estrutura populacional de Heteropterys pteropetala (Adr. Juss.), Malpighiaceae, em áreas de Cerrado sensu stricto submetidas a queimas bienais. Acta Bot. Bras. 19(4):927-934

Scholes, R.J. and S.R. Archer. 1997. Tree-grass interactions in savannas. Annu. Rev. Ecol. Evol. Syst. 28:517-44.

Silva, D.M., P.P. Loiola, N.B. Rosatti, I.A. Silva, M.V. Cianciaruso and M.A. Batalha. 2011. Os Efeitos dos Regimes de Fogo sobre a Vegetação de Cerrado no Parque Nacional das Emas, GO: Considerações para a Conservação da Diversidade. BioBrasil 1(2):26-39.

Soares, J.J., M.H.A.O. Souza and M.I.S. Lima. 2006. Twenty years of post-fire plant succession in a "cerrado", São Carlos, Sp, Brazil. Braz. J. Biol. 66(2B):587-602.

STATSOFT, Inc. 2004. Statistica (data analysis software system), version 7. www.statsoft.com.

Staver, A. C., S. Archibald and S.A. Levin. 2011. The global extent and determinants of savanna and forest as alternative biome states. Science 334:230-232.
Tilman, D. 2004. Niche tradeoffs, neutrality, and community structure: A stochastic theory of resource competition, invasion, and community assembly. Proc. Natl. Acad. Sci. USA 101(30):10854-10861.

Uhlmann, A., F. Galvão and S.M. Silva. 1998. Análise da estrutura de duas unidades fitofisionômicas de savana (Cerrado) no sul do Brasil. Acta Bot. Bras. 12(3):231-247.

Valkó, O., P. Török, B. Deák and B. Tóthmérész. 2014. Prospects and limitations of prescribed burning as a management tool in European grasslands. Basic Appl. Ecol. 15:26-33.

Valkó, O., A. Kelemen, T. Miglécz, P. Török, B. Deák, K. Tóth, J.P. Tóth and B. Tóthmérész. 2018. Litter removal does not compensate detrimental fire effects on biodiversity in regularly burned semi-natural grasslands. Sci. Total Environ. 622-623:783-789.

van Wilgen, B.W., N. Govender, H.C. Biggs, D. Ntsala and X.N. Funda. 2004. Response of savanna fire regimes to changing fire management policies in a large African National Park. Conserv. Biol. 18(6):1533-1540

Received December 13, 2017 Revised May 16, June 14, 2018 Accepted June 15, 2018 